\title{
Menerapkan Pola Pendidikan Rohani Anak Berkebutuhan Khusus (Attention Deficit or Hyperactivity Disorder)
}

\author{
Antonius Isharjono \\ Sekolah Tinggi Teologi El-Shadday, Surakarta \\ antonius@gmail.com
}

\begin{abstract}
Jesus once rebuked the disciples when they prevented the parents who brought their children from coming to Him. Jesus 'attention and ministry is the practical application of Moses' command to all the people of Israel. The commandment is a spiritual education that must be taught to children so that the next generation of Israelis remain connected as God's people. In the process of spiritual education to children, there are children who quickly grasp the teachings given from parents and their environment, but there are also children who have special needs, such as children with Attention Deficit Or Hyperactivity Disorder (ADHD). This research aims to show the education that Moses carried out as an educational pattern for children with ADHD. By using descriptive methods, the conclusion is that the spiritual education needs of children with ADHD must still be met even though in practice need special handling, and can use the patterns taught by Moses.
\end{abstract}

Keywords: ADHD; children with special needed; hyperactive; Moses education; spiritual education

\begin{abstract}
Abstrak: Yesus pernah menegur murid-murid ketika mereka menghalangi para orang tua yang membawa anak-anaknya datang kepada-Nya. Perhatian dan pelayanan Yesus merupakan penerapan praktis perintah Musa kepada seluruh umat Israel. Perintah itu adalah pendidikan rohani yang harus diajarkan kepada anak-anak supaya generasi penerus Israel tetap terhubung sebagai umat Tuhan. Dalam proses pendidikan rohani kepada anak, ada anak yang cepat menangkap ajaran yang diberikan dari orang tua dan lingkungannya, namun ada juga anak yang memiliki kebutuhan khusus, seperti anak penyandang Attention Deficit Or Hyperactivity Disorder (ADHD). Penelitian ini bertujuan untuk menunjukkan pendidikan yang dilakukan Musa sebagai pola pendidikan kepada anak-anak penyandang ADHD. Dengan menggunakan metode deskriptif, maka kesimpulannya, kebutuhan pendidikan rohani anak-anak penyandang ADHD harus tetap dipenuhi sekalipun pada praktiknya perlu penangan secara khusus, dan dapat menggunakan pola yang diajarkan oleh Musa.
\end{abstract}

Kata Kunci: ADHD; anak berkebutuhan khusus; hiperaktif; pendidikan Musa; pendidikan rohani

\section{Pendahuluan}

Model pendidikan rohani yang efektif bagi anak penyandang ADHD mengacu pada metode pendidikan rohani yang diajarkan Musa bagi masyarakat Israel. Pendidikan anak berkebutuhan khusus memang tidak dijelaskan secara langsung dalam Alkitab, tetapi metode pendidikan dalam Perjanjian Lama, khususnya yang diterapkan Musa kepada umat Israel dapat dijadikan sebagai dasar atau acuan bagi pendidikan anak penyandang ADHD.

Secara garis besar pendidikan itu meliputi mengerti dan menempatkan anak biologis dalam rencana keselamatan Allah bagi seluruh umat manusia. Rencana keselamatan Allah 
bagi dunia selalu melibatkan anak dari sejak pemanggilan Abraham. Pengutusan Musa tidak hanya memimpin umat Israel keluar dari perbudakan Mesir dan membawa masuk ke Tanah Perjanjian, tetapi pada kenyataannya Musa melakukan pendidikan rohani. Targetnya adalah perubahan sikap mental dari masyarakat budak menjadi bangsa yang kudus milik Allah dan kerajaan imam (Kel. 19:6). Penerapan pendidikan rohani yang diajarkan Musa meliputi: materi pendidikan, metode pendidikan, sarana prasarana pendidikan, pendidik dan peserta didik.

Pembahasan mengenai pendidikan anak, atau secara khusus pendidikan kerohanian anak-anak merupakan hal yang umum dalam praktik Pendidikan Agama Kristen atau pelayanan gereja. Seperti penelitian yang dilakukan oleh Handreas Hartono tentang pendidikan Kristen dalam keluarga yang bertujuan membentuk karakteristik anak. ${ }^{1}$ Pendidikan rohani kepada anak umumnya identik dengan pendidikan gerejawi berupa kelas di Sekolah Minggu. Pendidikan rohani kepada anak tidak serta merta membuat anak dapat bertumbuh sesuai dengan target atau rancangan yang dibuat oleh para pendidik Sekolah Minggu. Ada saja hambatan yang ditemui dalam pendidikan anak ini termasuk Sekolah Minggu. ${ }^{2}$ Selain itu juga persoalan dalam menghadapi kebutuhan khusus para anak-anak di Sekolah Minggu atau di sekolah umum dalam pelajaran Pendidikan Agama Kristen.

Menurut Johanes Hasugian dibutuhkan pendidikan khusus bagi anak-anak berkebutuhan khusus, yang sudah barang tentu berbeda dengan anak-anak pada umumnya. ${ }^{3}$ Ada banyak persoalan yang membuat anak-anak memiliki kendalanya sendiri dalam hal proses belajar. Pemaparan dalam artikel ini berfokus pada anak-anak berkebutuhan khusus, yakni para anak-anak penyandang ADHD. Belum ada pembahasan khusus atau penelitian mengenai pola pendidikan kerohanian yang seperti apa yang dapat diterapkan dalam mengajar anak-anak ADHD. Artikel membahas secara khusus pendidikan rohani bagi anak kebutuhan khusus ADHD dengan menerapkan pola pendidikan Musa.

\section{Pendidikan Rohani Anak Dalam Komunitas Israel}

Dalam Perjanjian Lama dijelaskan: Ishak, yaitu anak Abraham dilibatkan dalam ibadah korban, Kejadian 22:1-4. Memang anak Abraham tidak hanya Ishak, tetapi Ishak adalah anak yang lahir dari Sara, isteri Abraham, yang dari padanya Allah mengikat janji yang kekal kepada keturunannya. Dari Ishak lahir Esau dan Yakub. Tetapi kepada Yakublah Allah mengikat perjanjian yang kekal. Kemudian dari Yakub lahir 12 anak laki-laki yang merupakan cikal bakal bangsa Israel, suatu bangsa yang terdiri dari 12 suku.

\footnotetext{
${ }^{1}$ Handreas Hartono, "Membentuk Karakter Kristen Pada Anak Keluarga Kristen,” KURIOS (Jurnal Teologi dan Pendidikan Agama Kristen) 2, no. 1 (2014): 62-69, www.sttpb.ac.id/e-journal/index.php/kurios.

${ }^{2}$ Tanto Kristiono and Deo Putra Perdana, "Hambatan Dan Pelayanan Guru Sekolah Minggu Di Gereja Kristen Jawa Jebres Surakarta,” Jurnal Teologi Gracia Deo 1, no. 2 (2019): 90-100, http://www.sttbaptisjkt.ac.id/e-journal/index.php/graciadeo/article/view/9.

${ }^{3}$ Johanes Waldes Hasugian et al., "Education for Children with Special Needs in Indonesia," Journal of Physics: Conference Series 1175, no. 1 (2019).
} 
Keberadaan anak dalam komunitas Israel tidak dapat dilepaskan dari rencana keselamatan Allah atas umat manusia. ${ }^{4}$ Rencana keselamatan itu ada di dalam sejarah kehidupan Israel yang dimulai dari pemanggilan Abraham, (Kej. 12:1-3). Dari Abraham diteruskan kepada anaknya yaitu Ishak yang lahir dari Sara. Tuhan telah menetapkan garis keturunan yang lahir dari Sara untuk menggenapi keselamatan umat manusia. ${ }^{5}$ Kemudian diteruskan lagi kepada Yakub (Kej. 28:13-14; 3:11-12). Dari Yakub lahir sebuah bangsa yang disebut Israel, dimana kelahirannya merupakan intervensi Allah agar keselamatan sampai kepada bangsa-bangsa lain.

Pada zaman Musa, anak Israel harus mendapatkan pendidikan dan perlindungan, seperti yang tertulis dalam Ulangan 6:4-9. ${ }^{6}$

Dengarlah, hai orang Israel: TUHAN itu Allah kita, TUHAN itu esa! Kasihilah TUHAN, Allahmu, dengan segenap hatimu dan dengan segenap jiwamu dan dengan segenap kekuatanmu. Apa yang kuperintahkan kepadamu pada hari ini haruslah engkau perhatikan, haruslah engkau mengajarkannya berulang-ulang kepada anakanakmu dan membicarakannya apabila engkau duduk di rumahmu, apabila engkau sedang dalam perjalanan, apabila engkau berbaring dan apabila engkau bangun. Haruslah juga engkau mengikatkannya sebagai tanda pada tanganmu dan haruslah engkaumenuliskannya pada tiang pintu rumahmu dan pada pintu gerbangmu.

Ayat-ayat itu dikenal sebagai shema, yaitu syahadat iman yang harus dihafal dan dipelajari oleh setiap anak Israel.

Ayat-ayat itu juga mendandung unsur tanggung jawab orang tua terhadap anakanaknya. Ketika kebenaran itu diterapkan dalam kehidupan sehari-hari, muncul sebuah model pendidikan yang berpusat pada rumah tangga, yang dapat dilakukan sedini mungkin. Model pendidikan itu adalah, anak-anak harus belajar me-esakan Allah dan hidup bergantung pada Allah, karena Allah yang menjamin kebehagiaan mereka. Kebahagian dan kemakmuran merupakan pemberian Allah, tetapi bersyarat, yaitu bahwa tugas dan tujuan hidup mereka adalah untuk memuliakan Allah melalui satuan keluarga. Relasi itu harus dikembangkan sampai anak-anak betul-betul merasakan peranan Allah dalam setiap peristiwa yang dialami.

Musa diutus Tuhan untuk memimpin umat Israel keluar dari perbudakan Mesir menuju Tanah Perjanjian (Kel. 3:10). Dalam menjalankan amanat Allah itu, Musa tidak hanya sekadar memindahkan secara fisik dari Mesir ke Tanah Perjanjian, tetapi ia juga mendidik. Pendidikan yang dilakukan Musa adalah pendidikan yang mengarahkan pada keselarasan rencana keselamatan Allah yang telah dijanjikan kepada leluhur Israel, yaitu Abraham. Pendidikan itu harus membuahkan perubahan sikap mental dari masyarakat budak kepada kepada suatu bangsa yang kudus kepunyaan Allah, dan kerajaan imam (Kel. 19: 6).

\footnotetext{
${ }^{4}$ W.S. Lasor, D.A. Hubbard, F.W. Bush., Pengantar Perjanjian Lama 1, (Jakarta: BPK, 1993) 163-169

${ }^{5}$ John Gill, John Gill's Exposition Of The Entire Bible, (e-sword v6.5.0, 2002)

${ }^{6}$ Stanley Heath, Teologi Pendidikan Anak - Dasar Pelayanan Kepada Anak, (Bandung: Yayasan Kalam HIdup, 2005) 17-35.
} 
Pengutusan itu mengandung unsur mendidik. Mendidik kata bendanya adalah pendidikan. Istilah pendidikan dalam bahasa Latin disebut educare dan educere. ${ }^{7}$ Educare memiliki arti merawat, membesarkan, memelihara, dan memperkaya seseorang dengan gizi yang baik supaya bertumbuh sehat dan kuat. Educere mengandung arti menuntun seseorang keluar dari suatu keadaan atau situasi ke dalam situasi lain yang lebih baik. Mengacu pada arti kata educare dan educere, Musa telah melakukan kedua-duanya. Tugas yang dikerjakan Musa secara rinci dijelaskan sebagai berikut:

Pertama, yang nampak secara fisik Musa melepaskan umat Israel dari perbudakan Mesir. Namun secara keseluruhan, apa yang dilakukan Musa adalah merubah kehidupan umat Israel dari masyarakat budak kepada kehidupan sebagai umat Allah yang kudus. Selama ratusan tahun umat Israel hidup dalam cengkeraman bangsa yang tidak menyembah Allah, yaitu Mesir. Sikap mental orang Israel tercermin dalam kehidupan sehari-hari sebagai budak Mesir. Budak yang terbelenggu, yang tidak dapat lagi melihat pengharapan anugerah Allah yang menyelamatkan. Keluaran 5:20-21, menyatakan bahwa mereka tidak mengerti rencana pembebasan Allah melalui pengutusan Musa. Penolakan raja Mesir atas permohoan Musa untuk membawa umat Israel beribadah di padang gurun mengakibatkan beban pekerjaan yang diperberat yang ditanggungkan atas orang Israel. Hal itu justru ditanggapi secara negatif oleh umat Israel. Namun demikian Musa tetap melaksakan tugas pengutusan Allah, tidak hanya secara persuasif tetapi mendatangkan 10 tulah bagi Mesir. Tindakan itu adalah tindakan yang dramatis, yang nyata, yang dapat disaksikan oleh seluruh umat manusia, agar dunia mengetahui siapa Allah Israel, Keluaran 7-11.

Kedua, Musa membawa umat Israel keluar dari kegelapan masuk ke dalam terang, lepas dari kebodohan beralih kepada kehidupan yang cerdas dan berhikmat. Selama ratusan tahun umat Israel hidup dalam kegelapan. Setelah mereka keluar dari tanah Mesir, Musa mengarahkan dan menggantungkan seluruh kehidupan umat Israel kepada Allah yang telah melepaskan mereka. Peristiwa fisik yang mereka alami, mulai dari anak-anak sulung Israel yang selamat dari malaikat maut (Keluaran 12), laut terbelah airnya sehingga mereka dapat berjalan di tanah yang kering (Keluaran 14: 15-31), Tuhan menampakkan diri di gunung Sinai (Keluaran 19), merupakan pengalaman iman yang menggairahkan untuk memasuki kehidupan yang lebih baik, yaitu hidup dalam terang.

Ketiga, Musa memperlengkapi segenap umat Israel dengan berbagai kebutuhan. Selama dalam perjalanan menuju Tanah Perjanjian, Musa yang menjamin kebutuhan jasmani mereka, yaitu makan dan minum bagi mereka dan juga bagi ternak-ternaknya. Namun kebutuhan yang utama adalah pendidikan rohani, yang diajarkan secara kognitif maupun afektif. Secara kognitif, Musa memperlihatkan jalan keluar oleh perbuatan tangan Allah membelah laut ketika umat Israel dalam keadaan terjepit di tepi laut dan di belakangnya pasukan Mesir sedang mengejar. Batu karang Horeb, atas kehendak Allah

\footnotetext{
${ }^{7}$ B.S. Sidjabat, Mengajar Secara Profesional, (Bandung: Yayasan Kalam Hidup) 101
} 
ketika dipukul dengan tongkat Musa tiba-tiba mengaluarkan air yang berlimpah-limpah (Keluaran 17:6). Dan dalam banyak peristiwa, Musa mengajarkan bahwa Allah hadir secara nyata di tengah-tengah umat Israel. Secara afektif, Musa mengajarkan tentang tata cara ibadah untuk bersikap hormat kepada Allah, dan mengatur hubungan antar sesama sebagai umat Allah yang berbeda dibandingkan dengan bangsa-bangsa lain.

Keempat, Musa memberikan rasa aman selama empat puluh tahun perjalanan menuju Tanah Perjanjian. Rasa aman yang dilakukan Musa adalah mengalahkan orang Amalek yang menghadang Israel. Peristiwa lain adalah Musa menghancurkan patung lembu emas yang dijadikan berhala oleh orang Israel. Menghadirkan allah lain akan menghilangkan rasa aman bagi Israel. Umat Israel harus menyembah hanya kepada Allah saja, maka dampaknya adalah rasa aman yang nyata yang dapat dirasakan oleh seluruh umat Israel.

\section{Metode Penelitian}

Penelitian ini merupakan kajian kualitatif atas pola pendidikan Musa sebagai pola mengajar anak kebutuhan khusus ADHD. Metode yang digunakan adalah deskriptif, untuk mendeskripsikan model pendidikan Musa sebagai pola pendidikan bagi anak kebutuhan khusus ADHD. Demikian juga metode tersebut digunakan untuk mendeskripsikan tentang anak kebutuhan khusus ADHD.

\section{Model Pendidikan Musa}

Pendidikan yang diterapkan Musa nampak pada materi pendidikan, metode pendidikan, sarana prasarana pendidikan, pendidik dan anak didik. Materi pendidikan Musa berasal dari Allah sendiri yang disampaikan dalam perjumpaan di gunung Sinai, yaitu Dasa Titah. Dasa Titah adalah Sepuluh Hukum yang diberikan Allah sebagai pegangan hidup seharihari. Hukum-hukum ini berasal dari Allah dan mempunyai maksud atau tujuan yang kekal. Sepuluh Hukum dijelaskan secara rinci sebagai berikut:

Pertama, "Akulah TUHAN, Allahmu..." (Kel. 20:2). Tuhan adalah Allah yang membawa Israel keluar dari negeri Mesir, dari rumah perbudakan. Allah telah membebaskan mereka pada saat mereka tidak berdaya. Karena itu Allah menghendaki supaya umat Israel taat sepenuhnya kepada Allah. Kedua, "Jangan ada padamu allah lain di hadapanKu" (Kel. 20:3). Tuhan menghendaki supaya umat Israel setia kepadaNya, dan tidak memberikan ruang bagi allah-allah lain masuk dalam kehidupan mereka.

"Jangan membuat bagimu patung yang menyerupai apapun..." (Keluaran 20:4) Ini adalah prinsip hidup umat kepunyaan Allah yang berbeda dari bangsa-bangsa lain pada masa itu. Selama ratusan tahun mereka terbiasa hidup diantara patung dewa-dewi yang disembah oleh masyarakat Mesir. Musa mengajarkan umat Israel untuk memikirkan Allah dengan cara yang sama sekali berbeda.

"Jangan menyebut nama TUHAN, Allahmu dengan sembarangan..." (Kel. 20:7). Pada masa itu, mereka percaya dengan menggunakan nama seseorang dapat menguasai orang lain. Allah menyatakan nama-Nya kepada Musa, tetapi bukan berarti Musa dapat menggunakan nama itu untuk menguasai atau maksud-maksud tertentu kepada orang lain. 
Nama Allah tidak boleh digunakan untuk kegiatan-kegiatan magis dan sumpah menyumpah. Nama Allah itu dimaksudkan untuk menolong kita merenungkan siapa Dia, untuk menghormati-Nya sebagaimana Ia ada dan untuk bersekutu dengan Dia.

"Ingatlah dan kuduskanlah hari Sabat" (Kel. 20:8). Menentukan satu hari untuk beristirahat diantara 7 hari lainnya, belum dikenal sebelum zaman Musa. Perintah ini mengawali suatu adat baru yang kemudian hari diteruskan dalam kebiasaan Kristen tentang hari Minggu sebagai hari yang penting.

"Hormatilah ayahmu dan ibumu..." (Kel. 20:12) Perintah ini berada diantara keempat perintah yang pertama yang mengatur hubungan antara manusia dengan Allah, dan lima perintah yang terakhir mengatur kewajiban manusia terhadap sesamanya. Jelas bahwa orang tua penting bagi anak-anaknya. Mereka bersama-sama dengan Allah ikut dalam penciptaan putra-putrinya. Mereka mngajar anak-anaknya untuk mengasihi dan melayani Allah (Ul. 6:4-9). Karena itu orang tua berhak atas penghormatan, perlindungan, pemeliharaan dikala usia tua mereka. "Jangan membunuh...berzinah....mencuri,...memberi kesaksian dusta,... mengingini,"(Kel. 20:13-17). Perintah-perintah ini adalah dasar yang teguh untuk seluruh hubungan yang penuh damai dan penuh bahagia antar manusia.

\section{Metode Pendidikan Musa}

Kehidupan masyarakat Israel yang didasarkan pada hukum Musa tidak hanya mencakup soal ibadah dan hubungan sosial saja. Untuk keberlangsungan hidup sebagai umat yang taat, Musa juga menekankan bagaimana membesarkan anak dalam konteks pendidikan rohani dengan suatu metode yang efektif. Dalam komunitas Israel tercermin secara gamblang mengenai konteks sosial yang dirancang Allah untuk pembinaan iman. Konteks ini didefinisikan secara sederhana, yaitu anak-anak harus dibesarkan sebagai bagian dalam suatu komunitas yang penuh kasih dan kudus.

Di bawah kepemimpinan Musa, Israel tidak memiliki lembaga pendidikan formal untuk anak. Tidak ada sekolah yang didirikan oleh hukum Taurat dan tidak ada individuindividu yang dikhususkan sebagai guru-guru bagi kaum muda. Namun demikian anakanak tetap bertumbuh sesuai rancangan Allah. Sebab mereka mengikuti pola kehidupan yang memungkinkan anak-anak akan mengenal Allah secara pribadi.

Sarana dan prasana pendidikan yang diajarkan Musa tercermin dalam Ulangan 6:8-9, yaitu: "Haruslah juga engkau mengikatkanya sebagai tanda pada tanganmu dan haruslah itu menjadi lambang di dahimu, dan haruslah engkau menuliskannya pada tiang pintu rumahmu dan pada pintu gerbagmu." Musa menggunakan kotak-kotak kulit berukuran kecil, yang dalam bahasa Ibrani disebut teffilim untuk diisi dengan tulisan ayat-ayat torah kemudian diikat pada tangan kiri dan di dahi. Maksudnya adalah agar torah itu menjadi pedoman yang mengendalikan segala kegiatan tangan, dan memonitor segala pandangan mata, juga mengatur pergaulan rumah tangga, dan segala aktivitas ekonomi, politik, dan lain-lain. Disamping itu torah bisa dibcakan setiap saat dan berulang-ulang seperti mantera pada saat pada orang tua sedang bekerja di rumah, bekerja di kebun, berdagang, atau dalam 
perjalanan. Sarana lain adalah mezuza, yaitu kotak seperti diatas tetapi bahanya dari logam yang dipasang di pintu rumah sebelah kanan. Mezuza ini menggantikan percikan darah dari adat kuno (Keluaran 12:7). ${ }^{8}$

\section{Pendidik}

Komponen lain dalam membesarkan anak yang dipolakan untuk masyarakat Israel adalah keluarga. Keluarga terdiri dari orang tua, anak-anak, cucu, dan saudara-saudara lain yang sedarah. Dalam konteks pendidikan anak, Musa mendelegasikan kepada ayah dalam setiap keluarga karena ayah atau suami berada pada otoritas tertinggi. Tugas para ayah jika dirinci adalah sebagai berikut: Memperlengkapi anak didik dengan berbagai kebutuhan supaya bertumbuh kuat dan dewasa; menekankan pembentukan watak dan moral; memberikan teladan hidup dalam kehidupan sosial; pengalaman iman secara pribadi dengan Allah harus dikomunikasikan kepada generasi baru. Setiap keluarga secara konsisten dipandang sebagai pusat pengajaran. Maka dari itu setiap orang tua dipanggil Allah untuk menjalankan firman Allah kepada anak-anak mereka.

\section{Anak Didik}

Yang disebut anak adalah keturunan kedua dari orang tua, dan tidak disebutkan batasan usia. Jika ada sanak saudara, dan orang lain yang tidak sedarah tetapi tinggal serumah masuk dalam kategori anak. Mereka inilah dikategorikan sebagai anak didik. Sehingga kepada mereka inilah para orang tua memberikan pendidikan rohani seperti yang dikehendaki Musa (Ulangan 6:7).

\section{Anak Penyandang ADHD}

Menurut Sugiarmin, ${ }^{9}$ ADHD merupakan istilah yang sering muncul pada dunia medis yang belakangan ini gencar diperbincangkan dalam dunia pendidikan dan psikologi. Istilah ini memberikan gambaran tentang suatu kondisi medis yang disahkan secara internasional mencakup disfungsi otak, dimana individu mengalami kesulitan dalam mengendalikan impuls, menghambat perilaku, dan tidak mendukung rentang perhatian mereka. Anak yang menyandang ADHD akan mengalami berbagai kesulitan belajar, kesulitan berperilaku, kesuliatan sosial, dan kesulitan-kesulitan lain yang kait-mengkait. ${ }^{10}$

Menurut Grant Martin ${ }^{11}$, mengatakan bahwa ADHD terdiri dari tiga masalah pokok. Pertama, kesulitan dalam perhatian berkelanjutan. Kedua, pengendalian atau penghambatan impuls. Ketiga, kegiatan berlebihan. Dan masalah-masalah lain seperti: kesulitan mematuhi peraturan, instruksi, dan adanya variabilitas berlebih dalam merespon situasi, khususnya pekerjaan sekolah. Singkatnya, ADHD merupakan suatu gangguan perkembangan yang mengakibatkan ketidakmampuan mengatur perilaku, khususnya untuk

\footnotetext{
${ }^{8}$ J.Cairns, Tafsiran Kitab Ulangan, (Jakarta: BPK Gunung Mulia, 2008) 132-135

${ }^{9}$ M. Sugiarmin, Mpd adalah seorang pendiri Resource Centre bagi anak ADHD, autis, anak berkesulitan belajar dan pengajar tetap jurusan Psikologi di UPI.

${ }^{10}$ M. Sugiarmin, Mpd. \& Drs MIF. Bihaqi, MSi., Memahami Dan Membantu Anak ADHD, (Bandung: Aditama, 2008)

${ }^{11}$ Grant Martin adalah seorang psikolog Kristen di Heritage Counseling Associates Washington
} 
mengantisipasi tindakan dan keputusan masa depan. Anak penyandang ADHD relatif tidak mampu menahan diri untuk merespons situasi pada saat itu. Mereka benar-benar tidak bisa memiliki sumber biologis yang kuat yang ditemukan pada anak-anak dengan predisposisi keturunan.

Menurut Susan Nolen-Hoeksema ${ }^{12}$ Anak ADHD memperlihatkan ciri-ciri sebagai berikut

1. Kekurang-perhatian; Kekurang-perhatian ini juga disebut kesulitan perhatian atau sulit konsentrasi. Anak tidak memperhatikan hal-hal yang detail, kesulitan memusatkan perhatian dan membuat kesalahan-kesalahan sehingga orang lain menilai anak itu ceroboh. Tidak bisa mendengarkan dan tidak bisa mengikuti instruksi dengan baik, sehingga sering didapati tidak menyelesaikan tugas-tugas.

2. Hiperaktivitas; Anak ADHD suka mengerakkan anggota tubuh, misalnya menggoyangkan-goyangkan tangan atau kaki terus menerus tanpa tujuan yang jelas. Berlarian kesana-kemari, dan tidak bisa terlibat dalam aktivitas yang tenang.

3. Impulsive; Adalah suatu dorongan yang tidak dapat dikendalikan, contohnya anak suka menyela ditengah-tengah perbincangan orangtua, dan tidak bisa menunggu giliran.

4. Gangguan Kognitif Motorik; Yaitu gangguan belajar yang meliputi gangguan membaca, matematikal, mengarang, dan kemampuan motorik dan koordinasi.

\section{Gangguan Kemampuan Sosial}

Yaitu gangguan berkomunikasi, berbicara tidak jelas, dan suka menyela pembicaraan orang lain. Terhadap hubungan dengan teman-temannya, anak ADHD cenderung sering berkelahi dan suka membuat keributan di kelas.

\section{Pembahasan}

\section{Pelayanan Kepada Anak ADHD}

Grant Martin merumuskan pedoman-pedoman pelayanan kepada anak ADHD yang didasarkan pada hasil riset, pengalaman, dan nilai-nilai alkitabiah. ${ }^{13}$

- Memperlakukan anak ADHD sebagai anak yang cakap. Berarti ia harus mendapat dukungan dalam setiap usaha menjelajahi hal-hal baru yang menarik perhatian bagi mereka melalui cara apa saja yang masuk akal.

- Fokus pada apa yang anak mampu lakukan.

- Mencari kesempatan khusus bahwa orang-orang disekelilingnya senang dan menerima keberadaannya.

- Mengkomunikasikan empati dan pengertian terhadap kesulitan-kesulitan si anak dan mendorong harapannya tentang masa depan. Keimanan kepada Tuhan merupakan solusi mengatasi kesulitan-kesulitan yang dihadapi anak. Dan cinta kepada Tuhan lebih penting dan bersifat abadi.

\footnotetext{
${ }^{12}$ Penulis buku: "Abnormal Psychology”, (Published McGraw-Hill, New York, 2001)

${ }^{13}$ Grant L. Martin, Terapi Anak ADHD, (Jakarta: BIP, 2008) 151-261
} 
- Menanamkan dalam pikirannya bahwa kesalahan tidak sama dengan kegagalan. Diperlukan dorongan orangtua untuk menumbuhkan keyakinan pada anak agar berani mengerjakan apa saja yang mendatangkan manfaat.

- Lebih menghargai prosesnya daripada hasil akhirnya. Perlu diingat bahwa proses si anak mengerjakan berbagai pekerjaan itu yang harus dihargai.

- Memberikan kasih tanpa syarat. Komunikasikan cinta tanpa syarat kepada anak apapun yang terjadi, tidak perduli betapapun buruknya segala sesuatu. Dan hindari membandingkan anak dengan saudara-saudaranya.

- Bersikap realistis dengan harapan-harapan.

- Memberikan dorongan semangat untuk menerima tanggung jawab apapun. ADHD bukan penghalang untuk melakukan apapun dan bukan alasan untuk berperilaku buruk, atau melakukan kesalahan. Dengan demikian maka kemampuan anak akan berkembang.

- Memberikan dukungan dalam usaha mengatasi setiap persoalan. Konflik sering kali muncul di luar rumah. Jika anak dibiasakan mengatasi semua persoalannya maka ia akan bertumbuh mandiri sekalipun menghadapi persoalan yang lebih berat di lingkungan lain.

- Orang tua harus bisa membedakan tidak mau dengan tidak mampu. Hukuman atas ketidakmampuan anak bisa menimbulkan frustrasi, impulsif, dan cepat resah.

- Menciptakan anak pola hidup yang teratur. Orang tua harus tegas terhadap peraturan-peraturan yang diberlakukan. Misalnya: kapan bermain, belajar, dan beristirahat. Hal seperti ini akan membuat anak belajar mandiri.

- Perlu tetap menjaga agar para pendamping anak ADHD tidak terpengaruh negatif karena perilaku anak.

\section{Materi dan Sarana Pendidikan Anak ADHD}

Materi yang efektif untuk diajarkan kepada anak ADHD adalah pola hidup teratur. Untuk menerapkan pola hidup teratur adalah sebagai berikut:

- Membuat jadwal rutin. Anak harus diberi jadwal rutinitas mulai dari bangun tidur, mandi, makan, bermain, bersosialisasi, rekreasi, berdoa, dan lain-lain.

- Keterampilan-keterampilan sosial. Keterampilan sosial efektif untuk meningkatkan pengendalian diri yang mencakup:

- Entri sosial, mengajarkan bagaimana berinteraksi dengan anak-anak lain.

- Manajemen kemurahan, bentuknya bisa berbagi barang dengan anak lain, bermain secara kooperatif, menyapa orang lain, memberi dan menerima bantuan.

- Berkomunikasi. Ini bisa mulai dengan mempertahankan sebuah percakapan dengan anak lain, keterampilan mendengarkan, mengajukan pertanyaan yang relevan, bertukar giliran berbicara, dan berisikap ramah. 
- Penyelesaian konflik. Saat berebut mainan harus dikembalikan kepada pemiliknya.

- Dasar-dasar spiritual. Orang tua harus sedini mungkin memperkenalkan Kristus kepada anak ADHD. Karena secara alami konsentrasi anak ADHD sangat pendek, maka dalam mengajarkan kebenaran ini orang tua bisa menggunakan "buka tanpa kata." "14 Buka tanpa kata ini terdiri dari 5 lembaran warna: kuning, hitam, merah, putih, dan hijau. Kuning melambangkan sorga yang jalannya terdiri dari emas, dan menggambarkan suasana yang sangat menyenangkan, tidak ada kesedihan, tidak ada penjahat. Namun tidak semua orang bisa masuk sorga karena semua telah berdosa. Dosa dilambangkan dengan warna hitam. Hitam menggambarkan suasana yang sedih, gelap, dan tidak ada yang baik. Manusia menjadi tidak berdaya, sehingga Tuhan Yesus turun dari sorga untuk menolong umat manusia dengan cara disalib. Disalib darah Yesus mengalir keluar yang digambarkan dengan kertas warna merah. Oleh Darah Yesus dosa manusia disucikan yang digambarkan dengan kertas warna putih. Kemudian kertas warna hijau menggambarkan Taman Firdaus. Dengan alat peraga ini anak akan mengikuti dengan konsentrasi dan harus segera diakhiri dengan doa permohonan pengampunan dosa serta mengundang Yesus masuk dalam hati. Dengan demikian orang tua bisa meyakinkan kepada anak, bahwa anak ADHD dikasihi Tuhan dan diberi karunia khusus untuk memperlengkapi kebutuhan kehidupan yang kreatif dan lengkap.

\section{Metode Pendidikan Anak ADHD}

- Setiap materi yang diajarkan harus diulang-ulang sampai anak terpola.

- Memberikan hadiah jika anak berhasil melakukan apa yang diajarkan.

- Menghilangkan atau mengurangi tingkah laku yang tidak dikehendaki. Misalnya, tingkah laku yang merusak harus dihilangkan. Dalam hal ini orang tua harus tegas dan diperbolehkan menghukum tetapi tidak boleh disertai dengan perasaan emosi.

- Mengembangkaan tingkah laku yang dikehendaki dan memberi pujian.

- Menggunakan instruksi-instruksi indra dan keteladanan.

- Campur tangan Tuhan. Allah turut bekerja melalaui keajaiban-keajaibanNya.

\section{Pendidikan Anak ADHD Berbasis Keluarga}

Dengan memperhatikan tingkah laku anak ADHD, materi pendidikan dan metode pendidikan yang direkomendasikan oleh pakar psikologi umum maupun Kristen, maka model pendidikan yang efektif adalah pendidikan yang berbasis keluarga. Keluarga adalah lingkungan terdekat anak ADHD. Maka keluarga juga yang harus memperlihatkan sikap senang dan menerima keberadaannya. Dengan sikap seperti itu maka anak akan merasa aman. Perasaan aman memungkinkan anak mengembangkan potensi yang dimiliki tanpa perasaan takut.

\footnotetext{
${ }^{14}$ Leila Lewis, Mengajar Untuk Mengubah Kehidupan, (Bandung: Kalam Hidup, 1994) 86-87
} 
Model pendidikan berbasis keluarga adalah model pendidikan yang bisa menjangkau semua materi pendidikan dasar, yaitu: pola hidup teratur yang meliputi agenda kegiatan yang rutin, keterampilan-keterampilan sosial, dan dasar-dasar spiritual. Dalam pendidikan berbasis keluarga ini orang tua anak ADHD yang harus hadir sebagai pendidik. Sebab orang tualah yang pertama-tama mengetahui gejala ADHD. Dan pada umumnya anak akan merasa aman berhubungan dengan orang tuanya sendiri. Dalam hal ini orang tua perlu dibekali pengetahuan dan keterampilan-keterampilan menangani anak ADHD. Jadi orang tua mengajarkan nilai-nilai yang alkitabiah sekaligus menjadi teladan. Ketika anak melihat teladan mereka, ini akan menjadi pola pendidikan yang sangat efektif.

Model pendidikan berbasis keluarga ini merupakan model pendidikan yang diajarkan Musa kepada anak-anak Israel. Yaitu suatu model tanpa menggunakan lembaga pendidikan formal, sehingga bisa dilakukan secara luwes tanpa dibatasi ruang dan waktu. Di semua tempat, disepanjang waktu dan dalam situasi apapun juga orang tua bisa memberikan pendidikan rohani, dan menerapkan nilai-nilai kehidupan yang alkitabiah. Jadi secara singkat, setiap ucapan, perbuatan, keputusan-keputusan yang menyangkut apapun juga adalah sebuah materi pendidikan yang ditangkap oleh anak untuk ditiru dan dilakukan.

\section{Kesimpulan}

Tujuan pendidikan anak adalah merawat, membesarkan, memelihara, melengkapi anak dengan gizi yang baik agar bertumbuh dengan sehat dan kuat, guna masuk ke dalam kehidupan yang lebih baik. Untuk mencapai tujuan itu dalam konteks anak ADHD, pendidikan konvensional bukan satu-satunya model pendidikan yang dapat memenuhi kebutuhan anak. Sekolah Rumah atau pendidikan berbasis keluarga ini bisa menjadi jawaban untuk memenuhi kebutuhan anak. Karena tidak semua orang tua siap menerima anak ADHD, maka gereja diharapkan bisa mewadai persoalan umat dengan memberikan bekal dan pendampingan bagi anak ADHD.

\section{Referensi}

Cairns, J. Tafsiran Kitab Ulangan, Jakarta: BPK Gunung Mulia, 2008

Gill, John. John Gill's Exposition Of The Entire Bible, e-sword v6.5.0, 2002

Hartono, Handreas. "Membentuk Karakter Kristen Pada Anak Keluarga Kristen." KURIOS

(Jurnal Teologi dan Pendidikan Agama Kristen) 2, no. 1 (2014): 62-69.

www.sttpb.ac.id/e-journal/index.php/kurios.

Hasugian, Johanes Waldes, Suardin Gaurifa, Sipora Blandina Warella, Jusuf Haries

Kelelufna, and Josefien Waas. "Education for Children with Special Needs in

Indonesia." Journal of Physics: Conference Series 1175, no. 1 (2019).

Heath, Stanley. Teologi Pendidikan Anak - Dasar Pelayanan Kepada Anak, Bandung:

Yayasan Kalam HIdup, 2005.

Kristiono, Tanto, and Deo Putra Perdana. "Hambatan Dan Pelayanan Guru Sekolah Minggu Di Gereja Kristen Jawa Jebres Surakarta." Jurnal Teologi Gracia Deo 1, no. 2 (2019): 90-100. http://www.sttbaptisjkt.ac.id/ejournal/index.php/graciadeo/article/view/9. 
Lasor, W.S. D.A. Hubbard, F.W. Bush., Pengantar Perjanjian Lama 1, Jakarta: BPK, 1993. Lewis, Leila. Mengajar Untuk Mengubah Kehidupan, (Bandung: Yayasan Kalam Hidup, 1994

Martin, Grant L. Terapi Anak ADHD, Jakarta: BIP, 2008

Sidjabat, B.S. Mengajar Secara Profesional, Bandung: Yayasan Kalam Hidup.

Sugiarmin, M. Mpd. \& Drs MIF. Bihaqi, MSi., Memahami Dan Membantu Anak ADHD, Bandung: Aditama, 2008 